\title{
Travel-Related Carbon Dioxide Emissions from American Society of Landscape Architects Annual Meetings ๑
}

\author{
Rob Kuper
}

ABSTRACT The logo of the American Society of Landscape Architects (ASLA) proclaims it to be "Green Since 1899." Annual meetings convened by the ASLA necessitate that many attendees travel by air. Carbon dioxide emissions from aircraft operations accounted for 2-3 percent of annual global emissions in 2010. Emissions are rising, despite the need to remove atmospheric carbon dioxide and reduce global emissions by 45 percent before 2030 and 100 percent before 2050, relative to 2010 levels, to limit global warming to $1.5^{\circ} \mathrm{C}$. No public estimations of travel-related carbon emissions associated with ASLA annual meetings are available. Using two web-based carbon calculators, meeting programs, websites, handouts, and ASLA meeting attendance numbers, I performed two travel-related carbon emission estimations: for 2,821 education session featured speakers who presented at annual ASLA meetings in 2011 and between 2013 and 2019; and for annual ASLA meeting attendees between 1960 and 2019. By applying findings from scientific literature to these emission estimates, I also calculated the area of September Arctic sea ice loss that may be attributed to ASLA annual meetings; the labor productivity losses in purchasing power parity that may be associated with ASLA meeting emissions; and the quantity of trees that would be needed to negate the meeting-related quantity of atmospheric carbon dioxide. I conclude by suggesting alterations to the format of annual ASLA conferences that would eliminate travel-related emissions in the future and narrow the gap between the ASLA's actions and proclaimed values.

KEYWORDS Climate change, carbon footprint, valueaction gap, telecommunications, nearly carbon-neutral conference, video conference

(2) This open-access article is distributed under the terms of the CC-BY-NC-ND license (http://creativecommons.org/ licenses/by-nc-nd/4.0) and is freely available online at http://lj.uwpress.org

\section{INTRODUCTION}

In all but 1 of the 120 years since the founding of the American Society of Landscape Architects (ASLA) in 1899, landscape architects and allied professionals have convened in different locations across the United States. Meeting attendees now establish and maintain professional and personal relationships; earn continuing education units by attending workshops and general, education, and field sessions; inspect products and question product representatives in the EXPO; attend society meetings, banquets, and galas; and explore gardens, plazas, and cultural landscapes near meeting sites. Consequently, a portion of meeting registrants, product representatives, and ASLA staff traveled by air, and continue to do so, to attend annual meetings.

The Fifth Assessment Report (IPCC, 2014) prepared by the Intergovernmental Panel on Climate Change (IPCC) identified a "clear" relationship between human activities and increased concentrations of atmospheric greenhouse gases (e.g., carbon dioxide, methane, and nitrous oxide) that had not occurred in at least the past 800,000 years. Consequently, the global mean surface temperature has risen by approximately $1^{\circ} \mathrm{C}$. Global warming from past emissions is irreversible, and additional, delayed temperature increases attributable to past emissions would be minimal due to long-term oceanic heat storage and absorption of atmospheric carbon dioxide (Matthews \& Solomon, 2013).

Current and future emissions relate directly to future global surface temperatures, more hot days, and more frequent and intense heat waves, drought, wildfires, rainfall, floods, higher sea levels, ecosystem and species losses (IPCC, 2014), and possibly human suffering and death (Nolt, 2011, 2013 , 2015). Limiting global warming to $2^{\circ} \mathrm{C}$ above preindustrial levels (1850-1900) requires global 
annual emissions reductions of 3.2 percent beginning in 2020; a delay until 2032 requires double the reductions, although economic models estimate that annual emission reductions likely cannot exceed 5 percent (Stocker, 2013). The opportunity to limit global warming increase to $1.5^{\circ} \mathrm{C}$ by emission reductions alone expired in 2012. Relative to 2010 levels, by 2030 and 2050 humans must reduce emissions by 45 and 100 percent, to limit global warming to $1.5^{\circ} \mathrm{C}$ and remove carbon dioxide from the atmosphere, which is "subject to multiple feasibility and sustainability constraints" (IPCC, 2018, p. 19). Reliance only on emission reductions to limit warming to $2^{\circ} \mathrm{C}$ and $2.5^{\circ} \mathrm{C}$ yields expiration dates of 2027 and 2040 (Stocker, 2013). The societal inertia that must be overcome to reduce emissions and meet these dates is substantial (Matthews \& Solomon, 2013).

Past trends and the projected increase in demand for air travel serves as evidence of this societal inertia. Between 1940 and 2005, carbon dioxide emissions from aircraft increased from close to 0 metric tons $\left(\mathrm{tCO}_{2}\right)$ to 700 million $\mathrm{tCO}_{2}$ per year (Grote, Williams, \& Preston, 2014). In 2010, aircraft operations accounted for $2-3$ percent of total global human-induced carbon dioxide emissions (Owen, Lee, \& Lim, 2010), which is equal to the percentage of emissions from the combustion of coal, natural gas, oil, and other fuels in Canada and Mexico combined (Union of Concerned Scientists, 2019). If ground support equipment, upstream fuel consumption, routine maintenance, and aircraft manufacturing are included, the contribution of the air transportation industry to global emissions further increases (Liu et al., 2016). Efforts to reduce aircraft emissions with increased fuel efficiency, jet fuel (mineral-kerosene) alternatives, aircraft design, and changes in operations, coupled with predictions of rising demand for air travel, would likely increase emissions. They are also likely to increase aircraft weight and drag, require decades-long infrastructural alterations, and in the case of biofuels, immense amounts of land for cultivation, competition with food production, and alteration of existing land uses (Grote, Williams, \& Preston, 2014). Aside from these possibilities, a ticket fee increase of $\$ 690$ per $\mathrm{tCO}_{2}$ may reduce air travel demand and alter behavior enough to reach carbon neutrality, relative to 2020 aircraft emission levels (Grote, Williams, \& Preston, 2014).

ASLA members may be ethically obligated to support such a tax or other "planning, design, and construction policies and regulations that will enhance air quality such as multi-modal transportation facilities and measures to reduce fugitive dust, greenhouse gas emissions, and volatile organic compounds" (ASLA, 2017b, emphasis added). ASLA claims to be "fully engaged in addressing climate change," intends to "reduce the carbon footprint of the Society's signature meeting" (ASLA, 2019b), and positions itself as "a resource, leader, and role model organization on environmental stewardship and other key issues" (ASLA, 2019c, p. 8). The organization-, conduct-, and travel-related emissions associated with annual meetings may contribute more to climate change than to supposed solutions (Nordhagen et al., 2014) presented at annual meetings. Such solutions may also do more harm than good. Green roofs, bioretention basins, stormwater ponds, and vegetative swales have been shown to have net positive carbon footprints over a 30 -year lifetime; only rain gardens had net negative carbon footprints (Kavehei et al., 2018).

Although these forms of green stormwater infrastructure have benefits that may temper adverse effects of climate change, convincing clients and the general public to implement them may require that landscape architects and other allied professionals model low-energy behaviors. In two studies conducted by Attari, Krantz, and Weber (2016, 2019), respondents were more likely to support policy changes advocated by presenters related to carbon emissions, energy, and transit when they perceived the presenters as more credible, sincere, and trustworthy. Respondents exhibited higher trust levels when they believed that the presenters flew less, conserved energy at home, and used public transit more. Failing to alter high-energy behaviors, such as flying, that conflict with the statements, work, and ASLA Code of Environmental Ethics makes ASLA and its members vulnerable to ad hominem attacks, which could jeopardize their influence in the future. Thus, estimating, reducing, and ultimately eliminating meeting-related emissions is imperative if ASLA intends to be perceived as a model organization on environmental stewardship. Other professional 
or academic organizations of landscape designers, planners, and managers that profess similar values must also act accordingly.

This article estimates the travel-related carbon dioxide emissions related to ASLA annual meetings between 1960 and 2019. In addition, it attempts to determine how these emissions may be associated with various effects of climate change, particularly regarding September Arctic sea ice and labor productivity losses. Such associations may help ASLA members visualize and understand the potential near- and long-term consequences for which they have been, are, and will be responsible. The article concludes by suggesting alternative methods to annually convene landscape architects and allied professionals. The results of the study will help ASLA's effort to reduce or eliminate conferencerelated emissions, practice the organizational ethical code of conduct, and be perceived as an organizational role model.

\section{LITERATURE REVIEW}

\section{Conference-Related Carbon Dioxide Emissions}

Following the IPCC's Third Assessment Report in 2001, scholars began to estimate business- and conference-related carbon dioxide emissions from air travel (Becken, 2002; Desiere, 2016; Guterman, 2009; Hall, 2007; Hischier \& Hilty, 2002; Nevins, 2014; Roberts \& Godlee, 2007; Stohl, 2008; Stroud \& Feeley, 2014; Wynes et al., 2019). Several studies documented the inequitable distribution of emissions among average citizens in various countries and airborne conference attendees (Becken, 2002; Fox et al., 2009; Høyer, 2009; Nevins, 2014; Stohl, 2008). Hischier and Hilty (2002) reported that travel accounted for 96.3 percent of the energy demands and carbon emissions related to a conference, and that 6 percent of participants contributed to about 60 percent of the overall environmental impact. Conference organization, material production, and dissemination (i.e., booklets, programs, and bags) accounted for the remaining 4.7 percent of conference-related emissions. Klöwer (2019) found that just over one-third of attendees who traveled the furthest were responsible for about three-quarters of a conference's total carbon footprint. Stohl (2008) found that air travel accounted for 90 percent of conference attendees business travel-related emissions between 2005 and 2007; hotel use and ground transportation accounted for 5 and 3 percent, respectively. Thus, air travel-related emissions likely contribute the most to the carbon footprint of an ASLA annual meeting. Compared with other aspects of conference conduct on emissions, they warrant estimation. Moreover, efforts to reduce the carbon footprint of ASLA annual meetings to date have likely had little relative effect.

Study results challenge perceived benefits of conference attendance. University faculty respondents in one study rated conference presentations as the most important reason to travel by air, followed by conference attendance and networking, which were rated equally (Nursey-Bray et al., 2019).

Ninety-five percent of respondents thought air travel would contribute to a promotion (Nursey-Bray et al., 2019). Wynes et al. (2019) found that just under two-thirds of scholars' air trips were to conferences, and air travel-related emissions for attendees with a higher rank and salary were significantly higher than attendees with lower ranks and salaries. Yet Wynes et al. (2019) also reported that emissions did not correlate with the average number of authors per publication, the total number of citations on a published paper, number of authors, and authors at the same career stage. Given the aforementioned literature, I expected that established academicians and practitioners, specifically professors and principals, would more frequently participate in ASLA annual meeting education sessions, and consequently be responsible for emitting the greatest amount of carbon, in comparison with entry- and mid-level scholars and practitioners.

Three studies show that the choice of meeting sites relates to emissions. Stroud and Feeley (2015) determined that optimizing conference meeting locations would decrease emissions associated with each meeting. Spinellis and Louridas (2013) estimated travel-related carbon emissions associated with the presentation of 32,264 conference proceedings papers published between 1998 and 2008. Of 46 total author countries represented and 42 conference locations represented, U.S. authors and U.S. conference locations, respectively, accounted for the highest percentage and highest total weight of carbon dioxide. Of the ten U.S. author-conference location pairs that resulted in the highest carbon 
dioxide emissions, authors in nine pairs originated from coastal states and traveled to conference locations in California. A recent study by Klöwer (2019) illustrates this point. Attendees of the 2019 American Geoscience Union (AGU) meeting who came from east of Colorado contributed the most emissions among U.S. attendees due to air travel to San Francisco. U.S. attendees also contributed the most to conference-related emissions overall. An emission reduction of 76 percent, relative to 2019 levels, would require distributing physical attendance to future AGU meetings among three centrally located regional hubs and configuring virtual attendance for more than one-third of attendees. Based on this literature, I expected that travel-related emission estimations for East or West Coast ASLA annual meeting locations in 2011 and between 2013 and 2019 would be higher than those for meeting locations elsewhere in the United States.

\section{METHODS}

\section{ASLA Education Session Featured Speakers, 2011 and 2013-2019}

Three reasons led me to view emission estimations of featured speakers at education sessions as proxies for emissions from all meeting attendees. First, education session featured speakers' names and institutions (e.g., company, university, or municipality) from relatively recent annual meetings are available online or in print. Identifying and collecting information from a representative sample of prior meeting attendees would be difficult (if not impossible) to accomplish. Second, education sessions at each meeting are more numerous $( \pm 117)$ in comparison to general sessions (2), field sessions (10 to 15), and workshops $( \pm 5)$. Finally, education session featured speakers originate from across the United States and the world, unlike field session speakers, who live and practice near the meeting location.

I located ASLA Annual Meeting programs, handouts, and websites the organization made available to its members by mail prior to registration (ASLA, 2019a); annual meeting attendees (ASLA, 2018); online through the ASLA web site (2011, 2013, 2014, asla.org/conference); or online through ASLA conference websites (ASLA, 2015, 2016, 2017a). Spreadsheets created for each annual meeting contained education session codes, featured speakers' names and institution, city and state of origin, travel mode, and emission estimations. I identified speakers' points of origin from annual meeting handouts or websites; speakers' LinkedIn pages; office, municipality, or university websites; and general Internet searches. Regardless of the number of presentations within which speakers participated at a given meeting, travel-related emission estimations were recorded only once in a spreadsheet for each annual meeting.

Likely mode of travel. I determined the likely mode of travel by using a web-based mapping service to examine the distances from each featured speakers' point of origin to each annual meeting location. For speakers that originated in cities, suburbs, or larger metropolitan areas, I listed the city proper as the point of origin. For instance, several featured speakers originating from Watertown, Cambridge, or Somerville, Massachusetts, were presumed to originate from Boston. For speakers who originated outside or between metropolitan areas and would have obviously had to travel by air to attend a meeting, I assumed that they would travel overland to the nearest airport. Carbon emissions from overland travel were not estimated if the primary mode of travel was by air.

Four additional assumptions included the following:

- Classifying "local" speakers as those who lived in city suburbs or metropolitan areas where an annual meeting occurred. I assumed that these speakers would drive a car, take mass transit, bike, or walk to the meeting and emit little carbon dioxide relative to air travel. Local speakers may have emitted as much, less, or more carbon dioxide than they would have normally emitted on a typical day traveling to and from work.

- Speakers would likely travel by car if the distance between their point of origin and the meeting location resulted in a travel time of one and three hours.

- Speakers would travel by train, if available, and the distance between their point of origin and the meeting location resulted in a travel time of three to six hours. 
- Speakers would travel by air, rather than train, if the distance and resulting overland travel time exceeded six hours.

Generally, travel distances and times clearly indicated one likely travel mode over others. In those cases requiring a determination, I selected the mode of travel that would likely emit the least amount of carbon dioxide. Thus, the emission estimations are likely low.

\section{Estimations of Travel-Related Carbon Dioxide Emissions}

Many online carbon calculators exist. To acquire a range of emission estimations that may result from variations in methodologies, I selected and used two online carbon footprint calculators-Carbonfootprint.com and Carbonfund.org. The Carbon Footprint calculator is based on a methodology and 2018 conversion factors defined by the government of the United Kingdom. At least one other carbon footprint estimation is based on the emission factors provided by the United Kingdom (Wynes et al., 2019). The Carbonfund calculator is available on the Amtrak website and is based on airplane or train emission values on distance traveled.

Air travel. When using the Carbon Footprint calculator, I specified one passenger, "return trip," and "economy class" for each flight. The Carbon Footprint calculator determines the distances from selected airports using the great circle method and includes an 8 percent "distance uplift" factor to account for indirect aspects of each route, such as delaying an airborne aircraft. In defining trip characteristics in the Carbonfund calculator, I specified one passenger making a round trip in coach class.

Car travel. For car and train travel, mileage computation used an online mapping service from speakers' point of origin to the meeting location. Because Carbonfund does not permit users to enter specific mileage to compute car travel emissions, I used only the Carbon Footprint calculator. Car travel estimates used emission values associated with a 2013 Toyota Camry equipped with an automatic six-cylinder (S6) 2.5L engine, the second most popular car in the United States in 2013, according to Edmunds.com.
Train travel. After determining that the distance between a city of origin and a meeting site may have afforded train travel, I investigated whether train travel was available and whether the duration of travel time equaled three to six hours by visiting Amtrak.com. After determining that the results of the query met the assumption of train availability and travel duration, I entered the distance between cities for one passenger on "long-distance" train travel in the Carbon Footprint calculator. Round trips were accommodated by doubling single-trip results. The Carbonfund calculator computed only round-trip train travel emissions estimations.

\section{Emission Estimations of ASLA Annual Meetings, 1960-2019}

Using a three-step process, I estimated travel-related carbon dioxide emissions for annual meetings that took place between 1960 and 2019. First, I requested ASLA annual meeting attendance numbers for this period from the ASLA Library and Archives; ASLA fulfilled most of this request. Missing meeting attendance values were interpolated from the received values. Second, for annual meetings in 2011 and between 2013 and 2019, I estimated the number of airborne attendees for each meeting by multiplying the number of meeting attendees per year by the percentage of education session featured speakers that flew that year. Third, I estimated the travel-related carbon emissions of all meeting attendees in 2011 and between 2013 and 2019 by multiplying the number of estimated airborne attendees per year by the travel-related carbon emission value associated with education session featured speakers that year. For meetings that occurred in 2012 and between 1960 and 2010, I used the mean percentage of airborne education session featured speakers and emission weight across all meetings in 2011 and between 2013 and 2019. In cases where meetings between 1960 and 2010 took place in the same location as a meeting in 2011 and between 2013 and 2019, I used the percentages of airborne and emission weights from education session featured speakers associated with that location. For example, Philadelphia hosted the annual meeting in 2018, 2008, and 1972. Thus, I estimated the number of airborne meeting attendees by multiplying meeting attendance for each year by the percentage of 
education session featured speakers who flew in 2018 (49.4 percent). I then estimated emissions for these three years by multiplying the estimated number of airborne attendees by featured speakers' emission weight in $2018\left(0.25 \mathrm{tCO}_{2}\right)$.

\section{Effects of Meeting-Related Carbon Dioxide Emissions}

Radiative forcing. Carbon dioxide and other greenhouse gases emitted by aircraft at high altitudes interact with atmospheric particles differently than they do on the ground. Thus, the increased potential of aircraft emissions' contribution to global warming, which is known as a climate or radiative forcing factor, may be two to four or even five times that of emissions from ground sources (IPCC, 1999; Jungbluth \& Meili, 2019; Owen, Lee \& Lim, 2010). Online carbon calculators allow users to account for radiative forcing and vary in the factor specified. Accordingly, I computed travel-related emissions with and without radiative forcing factors of 1.891 and 2.7 for the Carbon Footprint and Carbonfund calculators, respectively.

September Arctic sea ice loss. Meeting attendees' travel-related emissions may contribute to sea ice loss. For every increase of $1 \mathrm{tCO}_{2}$ emitted between 1953 and 2015, $3 \mathrm{~m}^{2}\left( \pm 0.3 \mathrm{~m}^{2}\right)$ of September Arctic sea ice loss occurred (Notz \& Stroeve, 2016). If emissions continue at the current rate of 35 billion $\mathrm{tCO}_{2}$ annually, September Arctic sea ice will be completely lost sometime before 2050 (Notz \& Stroeve, 2016). Consequently, the Arctic Ocean would absorb more solar radiation than Arctic ice would reflect into the atmosphere and contribute to a positive feedback that would likely further increase global warming. Accordingly, I approximated the area of September Arctic sea ice loss associated with emissions from the ASLA Annual Meetings between 1960 and 2019, approximately the same period of time studied by Notz and Stroeve (2016).

Labor productivity loss. Chavaillaz et al. (2019) found a "robustly linear" relationship $(r>0.9, p<$ 0.008 ) between cumulative carbon dioxide emissions and labor productivity loss in agriculture, mining and quarrying, manufacturing, and construction due to increased heat exposure, particularly in equatorial regions. For every 1 trillion $\mathrm{tCO}_{2}$ emitted, global labor productivity decreases, on average, by $1.84,2.96$, and 3.61 percent of total GDP for simulations that modeled carbon dioxide concentration variations of 1 percent, and representative concentration pathways of 4.5 and 8.5, respectively. Moreover, based on 2011 international dollars in purchasing power parity, this relationship represents an annual loss of $\$ 0.59$ per $\mathrm{tCO}_{2}$. Such losses are most likely to occur in lower-income and middleincome countries where productivity losses may range from 2.99 to 5.91 percent, depending on the simulation. Accordingly, I multiplied the annual labor productivity loss value of $\$ 0.59$ per $\mathrm{tCO}_{2}$, adjusted for inflation, by the weight of carbon emissions associated with travel to each ASLA meeting between 1960 and 2019. The result represented the contribution to global GDP loss elsewhere because of ASLA-conference-related travel.

\section{Sequestering Meeting-Related Emissions with Trees}

To limit global warming to $1.5^{\circ} \mathrm{C}$, the IPCC (2018) stated that emission reductions and carbon sequestration must happen. Uncertainties exist related to the use of bioenergy with carbon capture and storage in an effort to remove atmospheric carbon dioxide and limit global warming to $2^{\circ} \mathrm{C}$ (Fuss et al., 2014). Thus, trees may be the most efficient and reliable mechanism for removing atmospheric carbon dioxide (Bastin et al., 2019). I drew on two sources to estimate the number of trees and time needed to remove meeting-related carbon dioxide from the atmosphere. First, the National Tree Benefit Calculator (www.treebenefits.com/calculator/) reports that a 3-inch-diameter Acer saccharum (sugar maple) planted in the northeastern United States will reduce 53 pounds of atmospheric carbon by sequestration and avoidance over one year. Generally, broadleaf trees reduce atmospheric carbon more than evergreen trees do, and some broadleaf tree species, such as black locust, ginkgo, and northern catalpa, reduce atmospheric carbon more than others. Nonetheless, for each meeting, I divided the travel-related emission estimations by 53 to estimate the number of trees needed to remove meeting-related atmospheric carbon dioxide over one year. While Acer saccharum does not grow ubiquitously throughout the United States, 
its use provides a common sequestration metric for this study.

Second, after accounting for potential energy savings, tree survival, and net sequestration over 100 years, McPherson and Kendall (2014) estimated that the 91,786 trees planted for the Million Trees Los Angeles project between 2006 and 2010 may sequester a total of $98,053 \mathrm{tCO}_{2}$ of carbon dioxide. Accordingly, I estimated the number of trees needed to sequester travel-related emissions for each meeting over 100 years by multiplying the meetingrelated emission estimations by 0.936 , the value returned after dividing trees planted by carbon sequestered in McPherson and Kendall (2014).

\section{Limitations}

Numerous limitations exist with the conduct of this study, two of which relate to the education session featured speakers. First, the estimations of travelrelated carbon emissions are based only on information related to education session featured speakers in 2011 and between 2013 and 2019. I did not estimate the travel-related carbon emissions of people presenting field sessions, general sessions, and workshops. Also excluded are the travel-related emissions of product representatives that participated in the EXPO, as well as ASLA staff who ran the conference. I did not estimate emissions associated with the transport of EXPO and other meeting-related products and materials. Accounting for additional travel and transport would increase carbon emissions for each meeting beyond the estimations that I present. Second, some featured speakers may not have presented, may have been replaced by someone whose travel resulted in more or less carbon emissions, or may have presented remotely by way of telecommunications software.

Two limitations pertain to use of online carbon footprint calculators. First, the assumptions that relate travel distance to time and mode may not have applied to some featured speakers. Some may have tolerated car rides in excess of three hours, or train rides exceeding six hours if train travel was available. Some may have preferred to travel by train if the duration equaled one to three hours. Other speakers may have not been willing to travel six hours by train and instead opted to travel by air. Second, featured speakers' car models and years varied from the 2013 Toyota Camry that I used to estimate car-related travel emissions. Thus, actual carbon emissions from car travel will differ from my estimations.

Two more limitations relate to changes in fuel efficiency and my interpolations of ASLA meeting attendance numbers. Grote, Williams, and Preston (2014) reported that aircraft fuel efficiency increased, on average, by about 1.5 percent a year between 1960 and 2008. The estimations of meeting-related emissions assume a uniform, modern rate of fuel use. Accounting for decreasing fuel efficiency from the present to 1960 at 1.5 percent a year would result in higher estimations of meeting-related emissions than I present in this study. Finally, the estimations of travel-related carbon emissions relied on interpolations between meeting attendance numbers that I received from ASLA. Use of actual meeting attendance numbers would alter the findings. Moreover, the estimations of meeting-related emissions relied on percentages of airborne education session featured speakers and their emission values. The actual percentages of airborne meeting attendees per meeting differed from my proxy values, as well as the actual emission values of airborne attendees. Thus, a replication of this study that includes these values, if available, will yield different results.

\section{RESULTS AND DISCUSSION}

\section{ASLA Education Session Featured Speakers, 2011 and 2013-2019}

I chose not to conduct statistical tests on emission estimations from 2011 and 2013-2019 education session featured speakers by meeting location. Although significant differences in speakers' emissions related to meeting locations may be of interest to readers and inform the selection of future meeting locations, the urgent need to drastically reduce and eventually eliminate carbon dioxide emissions (IPCC, 2018; Stocker, 2013) and alter ASLA members' behaviors renders such results moot.

Of the total number of featured speakers, 469 (16.6 percent) presented more than once (Figure 1). I found a significant Pearson's correlation coefficient of $0.533(p<0.001)$ between repeat speakers' number of presentations and raw emission values, which suggests that speakers who presented more 


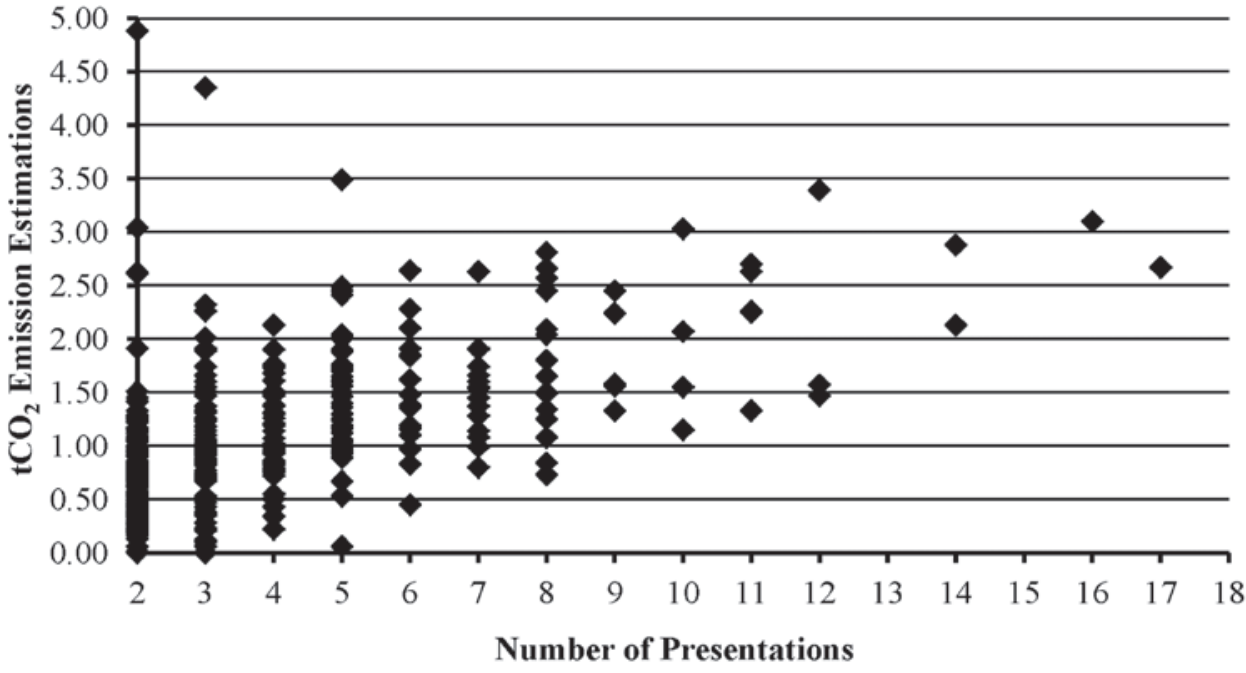

Figure 1

ASLA meeting speakers' emissions by presentation frequency. The plot excludes one outlier who participated in six presentations and may have been responsible for emitting $9.58 \mathrm{tCO}_{2}$ from air travel. frequently were responsible for significantly more emissions than those who presented in fewer presentations. More than half of repeat speakers $(n=238$, 50.8 percent) participated in two education sessions, 85 percent of repeat speakers $(n=399)$ participated in two to five sessions. Approximately another 10 percent $(n=49)$ participated in six to eight sessions. Of the 110 speakers who gave five or more presentations, 86 presented as principals, presidents, directors, partners, or similar upper leadership in private practice; 2 presented as senior associates; 10 presented as professors or associate professors at universities; 6 presented as directors of foundations or public entities; 3 presented as associates in private practices; 2 represented as product manufacturers; and the professional affiliation of one was unknown.

The frequency of repeat presentations across annual meetings support the results of Wynes et al. (2019) and suggestions in Attari, Krantz, and Weber (2016) and imply that speakers who presented in at least five sessions in 2011 and 2013-2019 were more likely to have higher salaries and have travel patterns that emit more carbon dioxide than other presenters and landscape architects in general. Moreover, the results suggest that these speakers are more likely to be older, established practitioners or scholars who travel the most in association with their business operation (Kroesen, 2013). As the results of Attari, Krantz, and Weber (2016, 2019) imply, the potentially high carbon footprint of these frequent speakers may compromise their professional credibility and make them more susceptible to attacks on their character. Moreover, public and private support for policies or strategies that these frequent speakers advocate, design, and oversee in implementing strategies to stop or adapt to the effects of climate change may be adversely affected. Education session speakers should also consider how their personal behaviors influence subordinates' behaviors and model their attitudes and actions accordingly. Influence by people of personal importance, among other factors, has significantly predicted the number of flights taken over a twelvemonth period (Morten, Gatersleben, \& Jessop 2018). Interview responses have also indicated that modeling by institutional superiors may reduce businessrelated air travel (Nursey-Bray et al., 2019).

I found a significant Pearson's correlation coefficient of $0.88(p<0.001)$ between institutions' (e.g., private practice, university, foundation, or public entity) number of presentations and raw emission values, which suggests that institutions that participated more frequently in education sessions were responsible for significantly more emissions than institutions that participated in fewer presentations (Figure 2). As argued by Nihlén Fahlquist (2009), the institutions that are most frequently represented at annual meetings may be more closely associated with environmental problems related to ASLA annual meetings. These institutions have the power and resources to disseminate information and create reasonable alternatives for employees and 
Figure 2

ASLA meeting institutions' emissions by presentation frequency. I excluded two outliers from the scatterplot: one institution may have been responsible for emitting $12.47 \mathrm{tCO}_{2}$ to participate in 67 presentations in 2011 and 2013-2019; another may have been responsible for emitting $30.48 \mathrm{tCO}_{2}$ to participate in 66 education sessions.

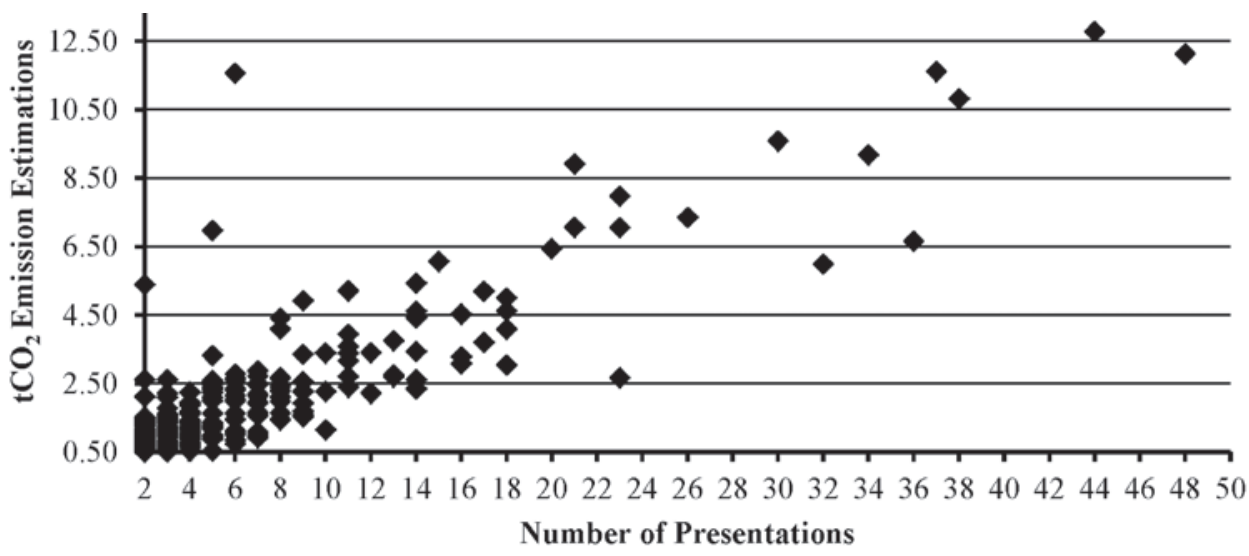

Table 1. Estimations of ASLA Meeting Education Session Featured Speakers' Travel-Related Carbon Dioxide Emissions

\begin{tabular}{|c|c|c|c|c|c|c|c|c|}
\hline Year & Location & Speakers & $\begin{array}{l}\text { Carbon } \\
\text { Footprint } \\
\left(\mathrm{tCO}_{2}\right)\end{array}$ & $\begin{array}{c}\text { Mean } \mathrm{tCO}_{2} \\
\text { per Speaker, } \\
\text { Carbon } \\
\text { Footprint }\end{array}$ & $\begin{array}{c}\text { Carbonfund, } \\
\mathrm{tCO}_{2}\end{array}$ & $\begin{array}{l}\text { Mean } \mathrm{tCO}_{2} \\
\text { per Speaker, } \\
\text { Carbonfund }\end{array}$ & $\begin{array}{l}\text { Mean } \\
\mathrm{tCO}_{2}\end{array}$ & $\begin{array}{l}\text { Mean } \mathrm{tCO}_{2} \\
\text { per Speaker }\end{array}$ \\
\hline 2019 & San Diego & 299 & 116.75 & 0.39 & 161.79 & 0.54 & 139.31 & 0.46 \\
\hline 2018 & Philadelphia & 395 & 79.86 & 0.21 & 118.89 & 0.29 & 98.96 & 0.25 \\
\hline 2017 & Los Angeles & 378 & 130.69 & 0.35 & 181.43 & 0.48 & 156.06 & 0.41 \\
\hline 2016 & New Orleans & 369 & 110.46 & 0.30 & 146.40 & 0.40 & 128.43 & 0.35 \\
\hline 2015 & Chicago & 355 & 80.23 & 0.22 & 106.76 & 0.30 & 93.50 & 0.26 \\
\hline 2014 & Denver & 350 & 97.77 & 0.28 & 133.02 & 0.37 & 115.40 & 0.33 \\
\hline 2013 & Boston & 338 & 84.66 & 0.25 & 122.27 & 0.36 & 103.47 & 0.31 \\
\hline \multirow[t]{3}{*}{2011} & San Diego & 337 & 132.54 & 0.40 & 184.05 & 0.55 & 158.99 & 0.48 \\
\hline & Total & 2,821 & 832.96 & & $1,154.61$ & & 994.11 & \\
\hline & Mean & 353 & 104.12 & 0.30 & 144.33 & 0.41 & 124.26 & 0.36 \\
\hline
\end{tabular}

members to act responsibly. Only after institutions make reasonable alternatives available to members must individuals assume responsibility for contributing to environmental problems. Furthermore, the principals, directors, professors, and other leaders who can influence subordinates and peers, model environmentally just behaviors, and create reasonable alternatives to attend annual meetings must assume institutional and individual responsibility for environmental problems related to ASLA annual meetings. For many speakers, exercising this responsibility may starkly contrast with the values they actively project to others inside and outside the profession of landscape architecture.

My computations showed that the travel patterns of individual education session speakers in 2011 and between 2013 and 2019 may have collectively emitted 833 to $1,155 \mathrm{tCO}_{2}$ into the atmosphere (Table 1). On average, travel by each speaker may have resulted in approximately 0.36 $\mathrm{tCO}_{2}$ emitted due to domestic air travel, which is lower than reported conference-related emissions 
Table 2. ASLA Meeting Speakers by Travel Mode, 2011, 2013-2019

\begin{tabular}{lcrrr}
\hline & Air & Car & Train & Local \\
\hline San Diego, 2019 & 268 & 24 & 0 & 7 \\
Philadelphia, 2018 & 195 & 15 & 137 & 47 \\
Los Angeles, 2017 & 307 & 9 & 0 & 62 \\
New Orleans, 2016 & 336 & 15 & 0 & 18 \\
Chicago, 2015 & 305 & 15 & 0 & 35 \\
Denver, 2014 & 315 & 1 & 0 & 33 \\
Boston, 2013 & 210 & 8 & 79 & 41 \\
San Diego, 2011 & 298 & 23 & 2 & 10 \\
\hline Means & $\mathbf{2 7 9}$ & $\mathbf{1 4}$ & $\mathbf{2 7}$ & $\mathbf{3 2}$ \\
\hline
\end{tabular}

from international travel (Desiere, 2016; Nevins, 2014; Spinellis \& Louridas, 2013). Approximately 80 percent of speakers probably traveled by air to meetings, whereas smaller percentages may have lived locally or traveled by train or car (Table 2). Air travel accounted for more than 98 percent of travel-related carbon emissions to and from the eight annual meetings (Figure 3). These findings approximate those reported in Hischier and Hilty
(2002) and Stohl (2008). They are higher than the reports in two other studies (Fox et al., 2009; Nevins, 2014).

The potential impact of air travel-related emissions is greater if radiative forcing is considered. Based on my estimations and radiative forcing factors presented by Carbon Footprint (1.891) and Carbonfund (2.7), featured speakers' total air travel-related emissions for all meetings in 2011 and between 2013-2019 may result in an atmospheric warming effect equal to 1,575 to $3,117 \mathrm{tCO}_{2}$.

On average, three or more featured speakers typically originated from 21 of 72 cities of origin (Table 3). By region, an average of 132 presenters a year originated from seven East Coast cities of the United States. Seventy-eight featured speakers originated from six West Coast cities, 35 speakers typically originated from three Midwestern cities, and 17 speakers originated from four cities in the South or southwestern United States. Between 2011 and 2019, three meetings took place on the West Coast, two on the East Coast, two in the Mountain West (including Phoenix, in 2012), one in the Midwest, and one in the South. These findings indicate that featured speakers likely emitted the least carbon dioxide by collectively traveling to Chicago, Philadelphia, and Boston, followed by Mountain West, South, and West Coast cities. Taken together, the concentration of featured speakers in East Coast

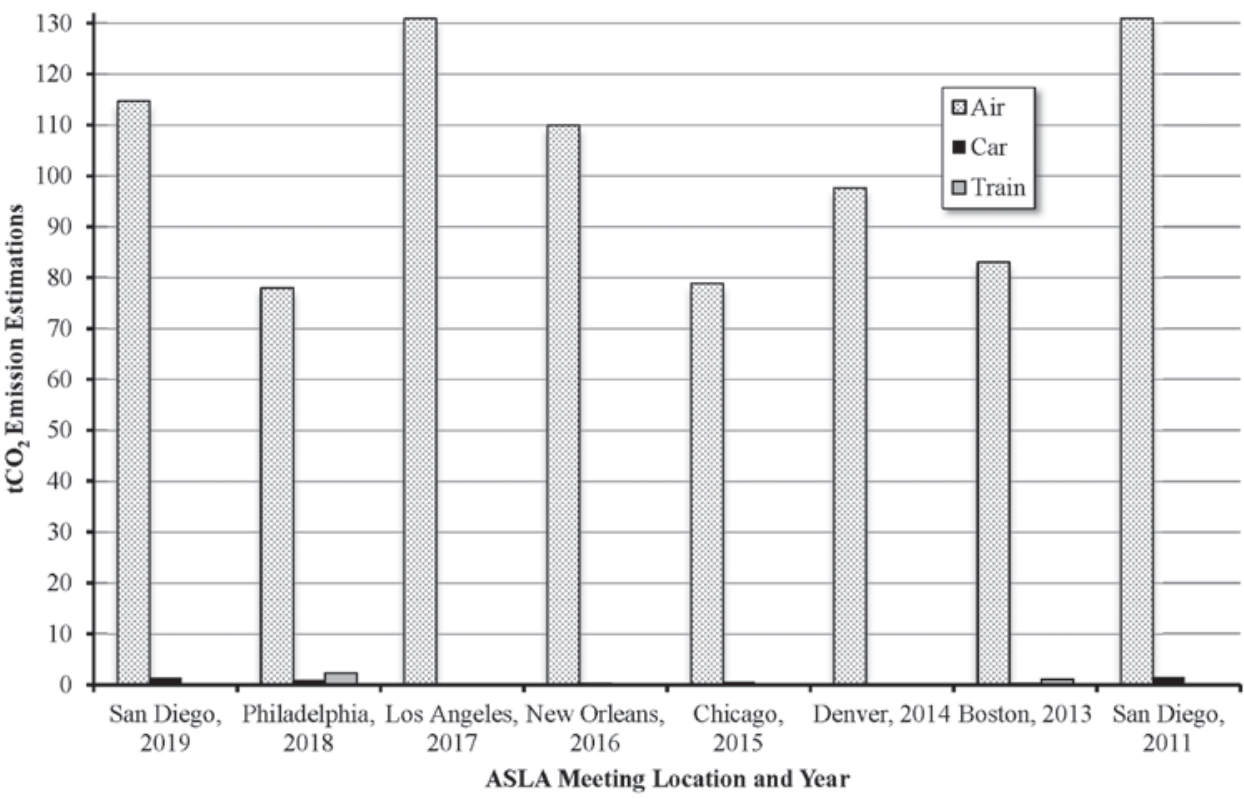

Figure 3

ASLA meeting speakers' emissions by travel mode. I assumed that emissions related to speakers who live and practice in the city where meetings took place equaled zero. 


\begin{tabular}{|c|c|c|c|c|c|c|c|c|c|c|}
\hline City of Origin & $\begin{array}{c}2019 \\
\text { San Diego }\end{array}$ & $\begin{array}{c}2018, \\
\text { Philadelphia }\end{array}$ & $\begin{array}{c}2017, \\
\text { Los Angeles }\end{array}$ & $\begin{array}{c}2016, \\
\text { New } \\
\text { Orleans }\end{array}$ & $\begin{array}{l}2015, \\
\text { Chicago }\end{array}$ & $\begin{array}{l}\text { 2014, } \\
\text { Denver }\end{array}$ & $\begin{array}{l}\text { 2013, } \\
\text { Boston }\end{array}$ & $\begin{array}{c}\text { 2011, } \\
\text { San Diego }\end{array}$ & Mean & $\begin{array}{c}\text { ASLA } \\
\text { Members, } \\
\text { October } \\
2019\end{array}$ \\
\hline New York City & 32 & 43 & 50 & 43 & 44 & 48 & 39 & 28 & 41 & 200 \\
\hline $\begin{array}{l}\text { Boston/ } \\
\text { Cambridge }\end{array}$ & 32 & 39 & 39 & 38 & 30 & 31 & 41 & 26 & 35 & 199 \\
\hline San Francisco & 27 & 25 & 43 & 27 & 31 & 25 & 22 & 27 & 28 & 201 \\
\hline Los Angeles & 20 & 28 & 62 & 12 & 10 & 16 & 17 & 23 & 24 & 169 \\
\hline Philadelphia & 19 & 47 & 14 & 16 & 17 & 14 & 24 & 17 & 21 & 180 \\
\hline Washington, DC & 8 & 23 & 21 & 25 & 25 & 24 & 23 & 19 & 21 & 152 \\
\hline Chicago & 7 & 17 & 10 & 11 & 35 & 8 & 8 & 16 & 15 & 150 \\
\hline Denver & 15 & 6 & 12 & 19 & 14 & 23 & 11 & 18 & 15 & 145 \\
\hline Seattle & 8 & 17 & 11 & 8 & 20 & 13 & 8 & 8 & 12 & 296 \\
\hline Intercontinental & 6 & 10 & 6 & 9 & 4 & 5 & 8 & 6 & 7 & NA \\
\hline Austin & 9 & 5 & 7 & 5 & 5 & 6 & 6 & 5 & 6 & 178 \\
\hline Charlottesville & 1 & 12 & 4 & 3 & 2 & 5 & 5 & 12 & 6 & 158 \\
\hline San Diego & 6 & 5 & 6 & 5 & 8 & 4 & 7 & 10 & 6 & 181 \\
\hline Baltimore & 7 & 6 & 1 & 7 & 5 & 4 & 1 & 6 & 5 & 94 \\
\hline $\begin{array}{l}\text { Minneapolis/ } \\
\text { St. Paul }\end{array}$ & 2 & 4 & 3 & 4 & 7 & 6 & 6 & 6 & 5 & 125 \\
\hline Portland, OR & 4 & 2 & 14 & 7 & 2 & 5 & 9 & 1 & 5 & 171 \\
\hline Atlanta & 1 & 4 & 6 & 5 & 4 & 4 & 3 & 8 & 4 & 110 \\
\hline Dallas/Ft. Worth & 3 & 6 & 4 & 2 & 3 & 6 & 3 & 5 & 4 & 201 \\
\hline Albuquerque & 2 & 1 & 7 & 1 & 1 & 7 & 0 & 5 & 3 & 72 \\
\hline Sacramento & 7 & 2 & 5 & 2 & 2 & 3 & 2 & 2 & 3 & 66 \\
\hline Toronto, Canada & 6 & 3 & 1 & 3 & 0 & 4 & 3 & 5 & 3 & 86 \\
\hline $\begin{array}{l}\text { Cities } \\
\text { represented }\end{array}$ & 70 & 76 & 60 & 75 & 73 & 76 & 78 & 68 & 72 & - \\
\hline
\end{tabular}

cities likely contributed to higher emissions associated with meetings in West Coast cities because of increased air travel. Furthermore, the high volume of speakers from the East Coast may have contributed to lower emissions associated with East Coast meetings from decreased air and increased train travel.
Featured speakers who originated from international locations in 2011 and between 2013 and 2019 accounted for emissions that are approximately equal to those of the 2014 meeting in Denver and more than those of the 2013, 2015, and 2018 meetings (Table 4). Each year, the international air travel of 6 to 18 speakers accounted for 8 to 16 percent of 
Table 4. International and Intercontinental ASLA Meeting Featured Speakers' Travel-Related Emissions

\begin{tabular}{|c|c|c|c|c|c|c|}
\hline $\begin{array}{l}\text { Meeting } \\
\text { Year }\end{array}$ & $\begin{array}{l}\text { International } \\
\text { Travelers }\end{array}$ & $\begin{array}{l}\text { Intercontinental } \\
\text { Travelers }\end{array}$ & $\begin{array}{c}\text { Carbon } \\
\text { Footprint, } \mathrm{tCO}_{2}\end{array}$ & $\begin{array}{c}\text { Carbon Footprint, } \\
\text { Percent of Total } \mathrm{tCO}_{2}\end{array}$ & Carbonfund, $\mathrm{tCO}_{2}$ & $\begin{array}{c}\text { Carbonfund, } \\
\text { Percent of Total } \mathrm{tCO}_{2}\end{array}$ \\
\hline 2019 & 16 & 6 & 13.40 & 11.48 & 19.13 & 11.82 \\
\hline 2018 & 16 & 10 & 13.51 & 16.92 & 19.21 & 16.16 \\
\hline 2017 & 11 & 6 & 10.50 & 8.03 & 14.90 & 8.21 \\
\hline 2016 & 17 & 9 & 18.69 & 16.92 & 25.08 & 17.13 \\
\hline 2015 & 6 & 4 & 7.15 & 8.91 & 10.27 & 9.62 \\
\hline 2014 & 11 & 5 & 9.12 & 9.33 & 12.68 & 9.53 \\
\hline 2013 & 18 & 8 & 11.63 & 13.74 & 16.50 & 13.49 \\
\hline 2011 & 16 & 6 & 13.55 & 10.22 & 18.72 & 10.17 \\
\hline Totals & 111 & 54 & 97.55 & 11.94 & 136.49 & 12.02 \\
\hline
\end{tabular}

Note: Values for international travelers include intercontinental travelers.

education session speakers' total emissions. Overall, international travelers each were responsible for, on average, 0.88 to $1.23 \mathrm{tCO}_{2}$ of emissions, approximately three times the average for all speakers combined in 2011 and between 2013 and 2019.

\section{ASLA Annual Meetings, 1960-2019}

Between 1960 and 2019, ASLA annual meetings occurred in Ontario, Canada, the District of Columbia, and 25 U.S. states, including Hawaii. Past ASLA annual meetings occurred in nine of the ten most popular global conference locations (all in the United States, except Beijing) (Spinellis \& Louridas, 2013). Thirty-one of 60 ASLA meetings occurred in coastal U.S. locations that result in high-level carbon emissions from cross-country air travel: cities in Hawaii, Connecticut, New York, and Washington each hosted one meeting; Massachusetts and Oregon hosted two; Texas hosted three; Florida, Pennsylvania, and the Washington, DC, area hosted four; and cities in California hosted a total of nine meetings.

On average, for each year between 2011 and 2019, 4,582 airborne meeting attendees may have collectively emitted $15,025 \mathrm{tCO}_{2}($ mean $(M)=1,669$ $\mathrm{tCO}_{2} / \mathrm{yr}$ ) into the atmosphere, which is associated with a total labor productivity loss of $\$ 9,433$
( $M=\$ 1,048 / \mathrm{yr})$ and September Arctic sea ice loss of $45,075 \mathrm{~m}^{2}\left(M=5,008 \mathrm{~m}^{2} / \mathrm{yr}\right)$ (Table 5$)$. This area is approximately equal to a rectangle as wide as the reflecting pool that extends from the Lincoln Memorial to the elliptical path surrounding the Washington Memorial in Washington, DC. Between 2011 and 2019, more than 69,000 sugar maples would be needed, on average, each year to remove an equivalent quantity of atmospheric carbon dioxide. In total, 625,000 sugar maples, or their equivalent, may sequester the travel-related emissions associated with these nine meetings alone. Alternatively, removing atmospheric emissions for these meetings over 100 years could require 14,063 sugar maples ( $M=1,563 / \mathrm{yr})$.

After accounting for radiative forcing, ASLA meeting attendees between 2011 and 2019 may have contributed to an atmospheric warming effect equal to 23,943 to $46,790 \mathrm{tCO}_{2}$ (Table 5) due to travel.

Travel to four-day ASLA annual meetings between 1960 and 2019 may have resulted in the emission of 38,429 to $52,545 \mathrm{tCO}_{2}(M=45,860$ $\mathrm{tCO}_{2}$ ) (Table 5), which is associated with a total labor productivity loss of over $\$ 20,900$ in purchasing power parity and a September Arctic sea ice loss of 115,287 to $157,635 \mathrm{~m}^{2}$, the mean of which $(M=$ $137,587 \mathrm{~m}^{2}$ ) equals in area the reflecting pool in 


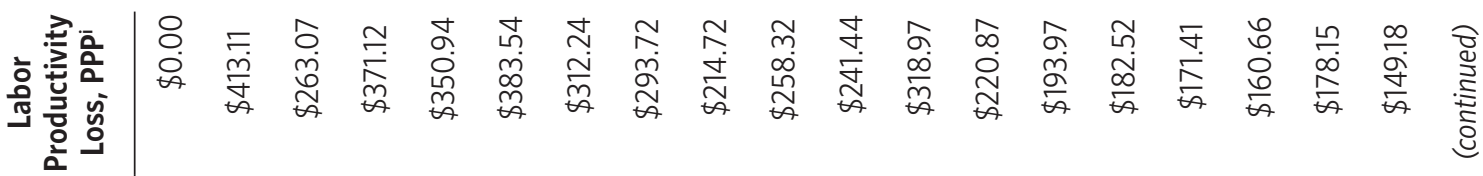

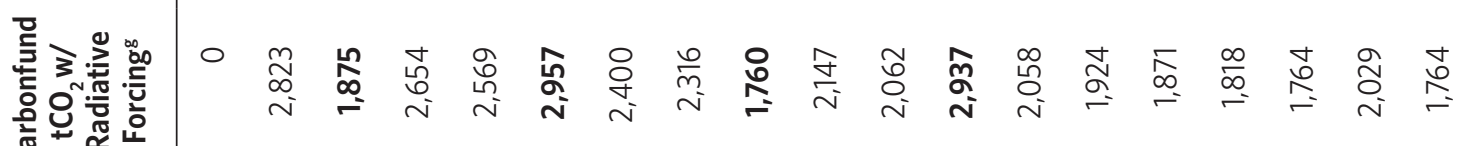

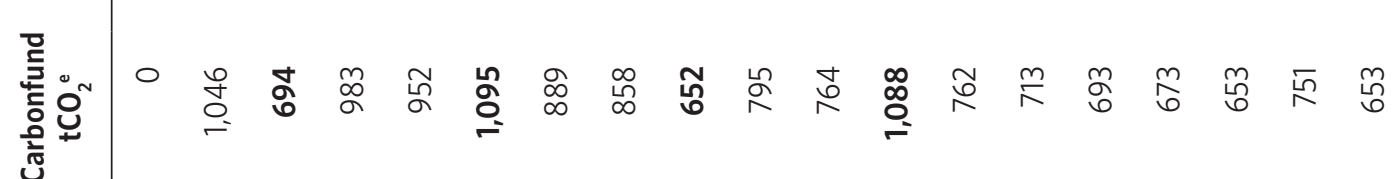

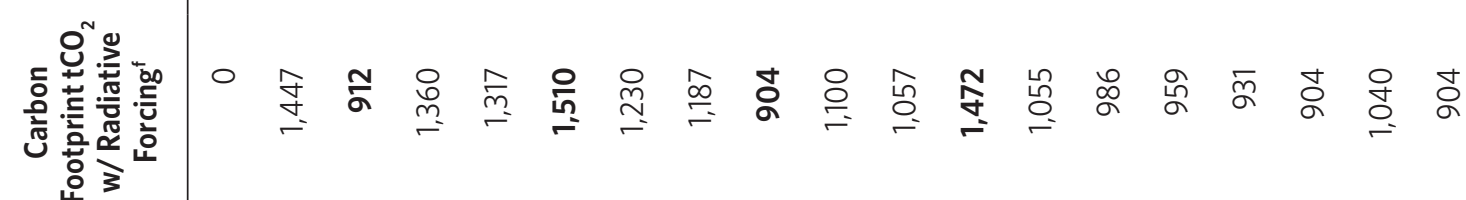
蒡。 $\frac{0}{\frac{0}{x}}$

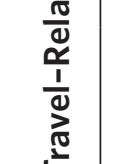$$
\text { 닌 }
$$$$
\text { 享 }
$$$$
4
$$$$
\text { 든 }
$$

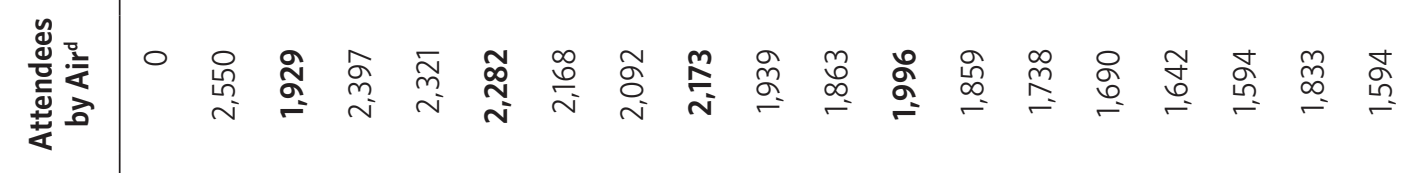

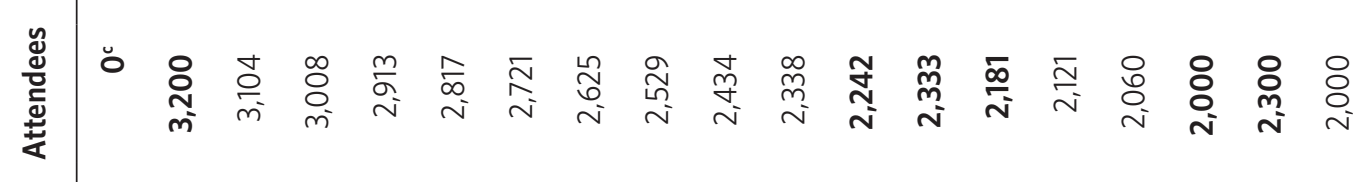

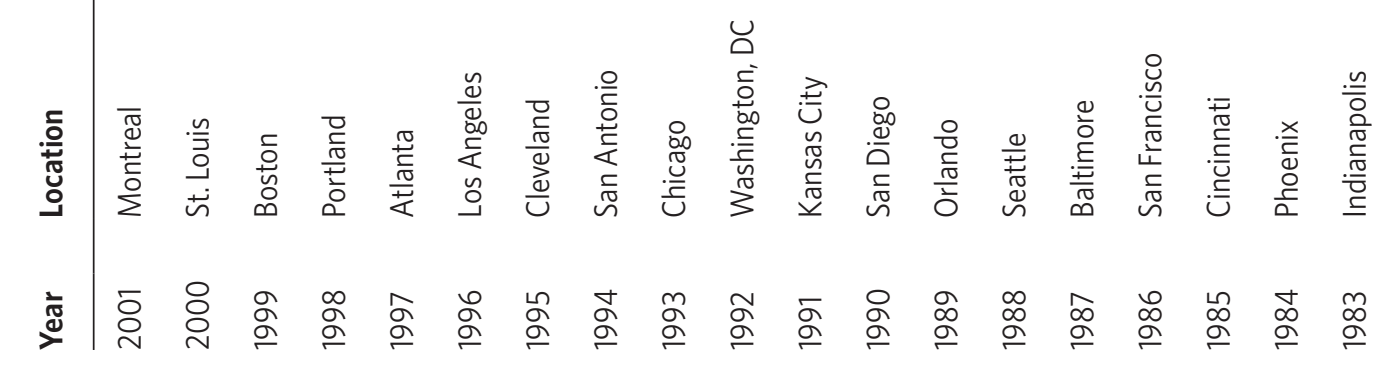




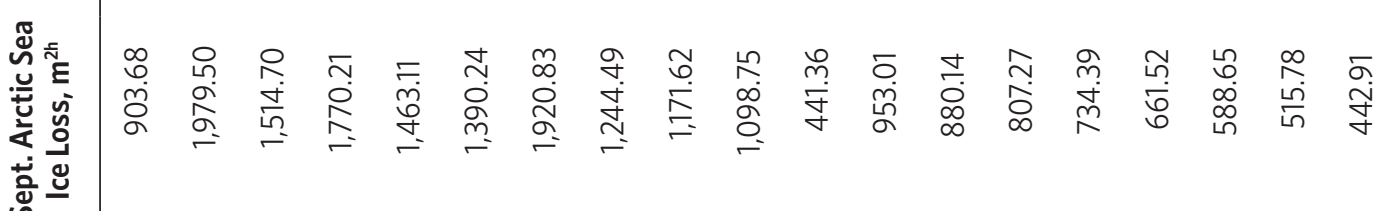

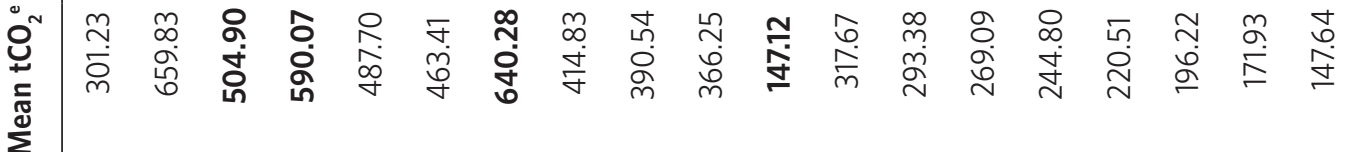

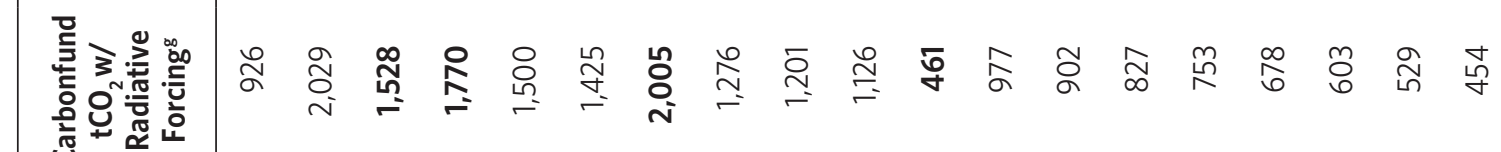
처원

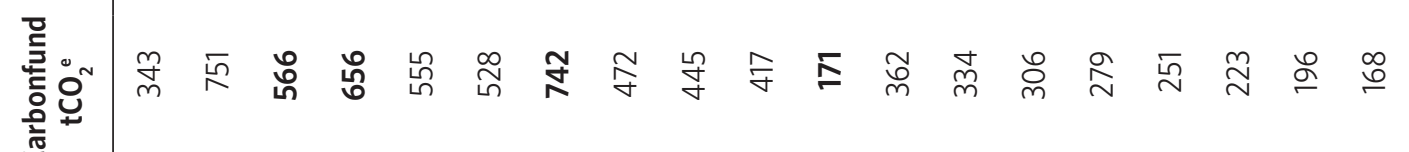

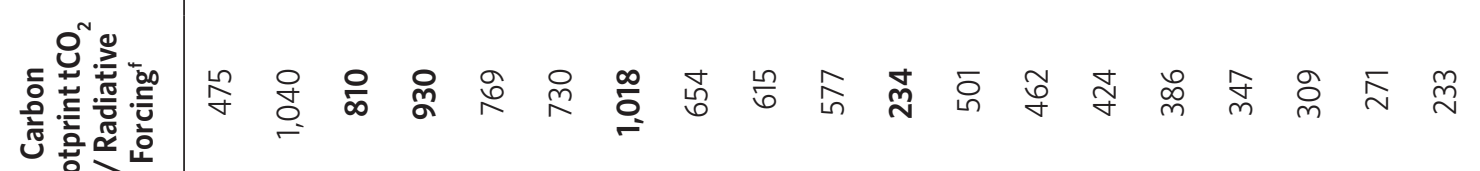
U

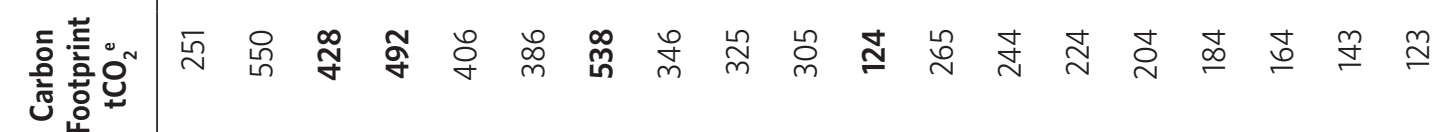
竧旁妾

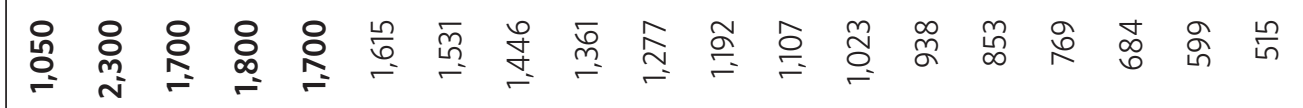




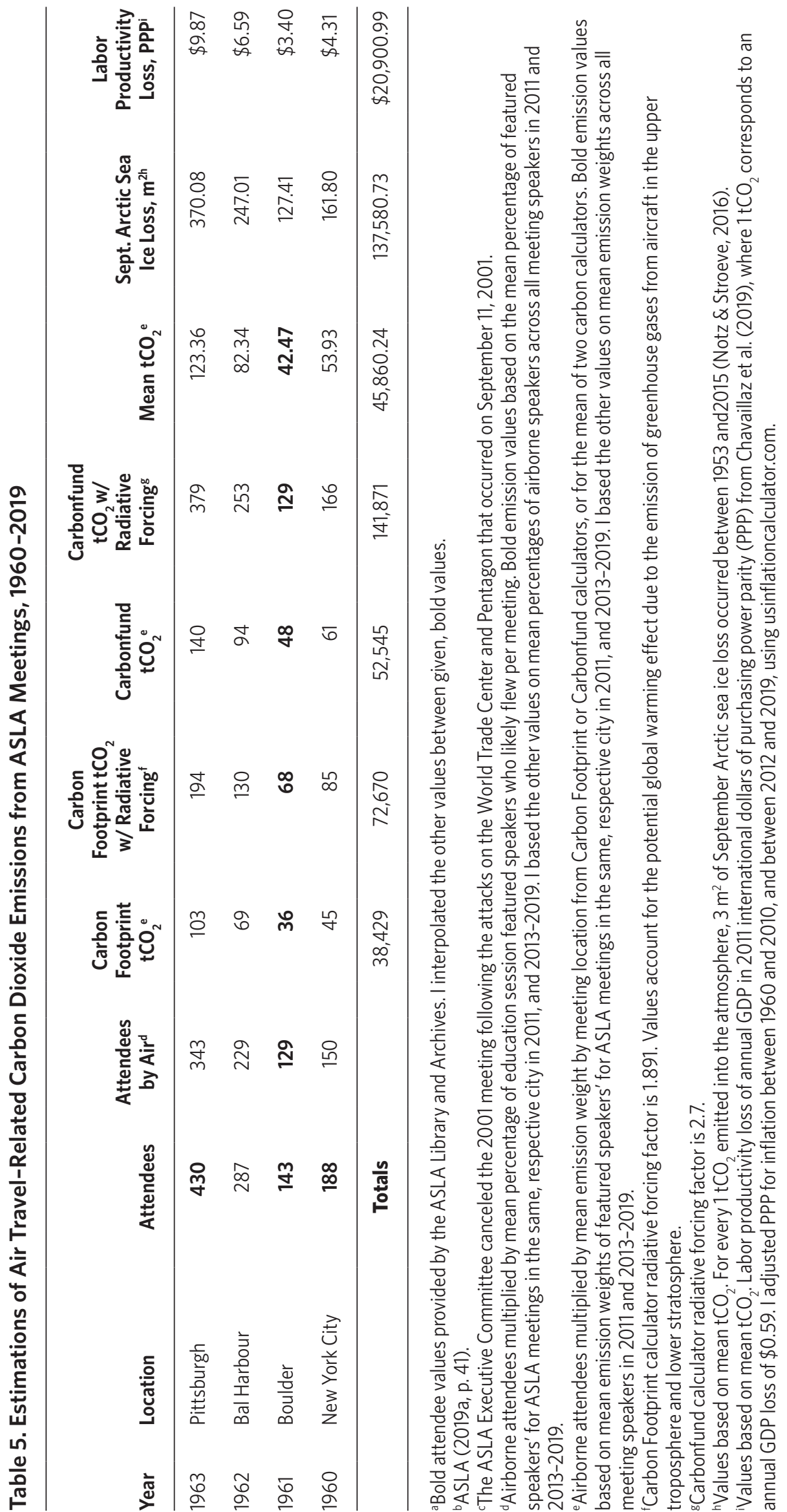




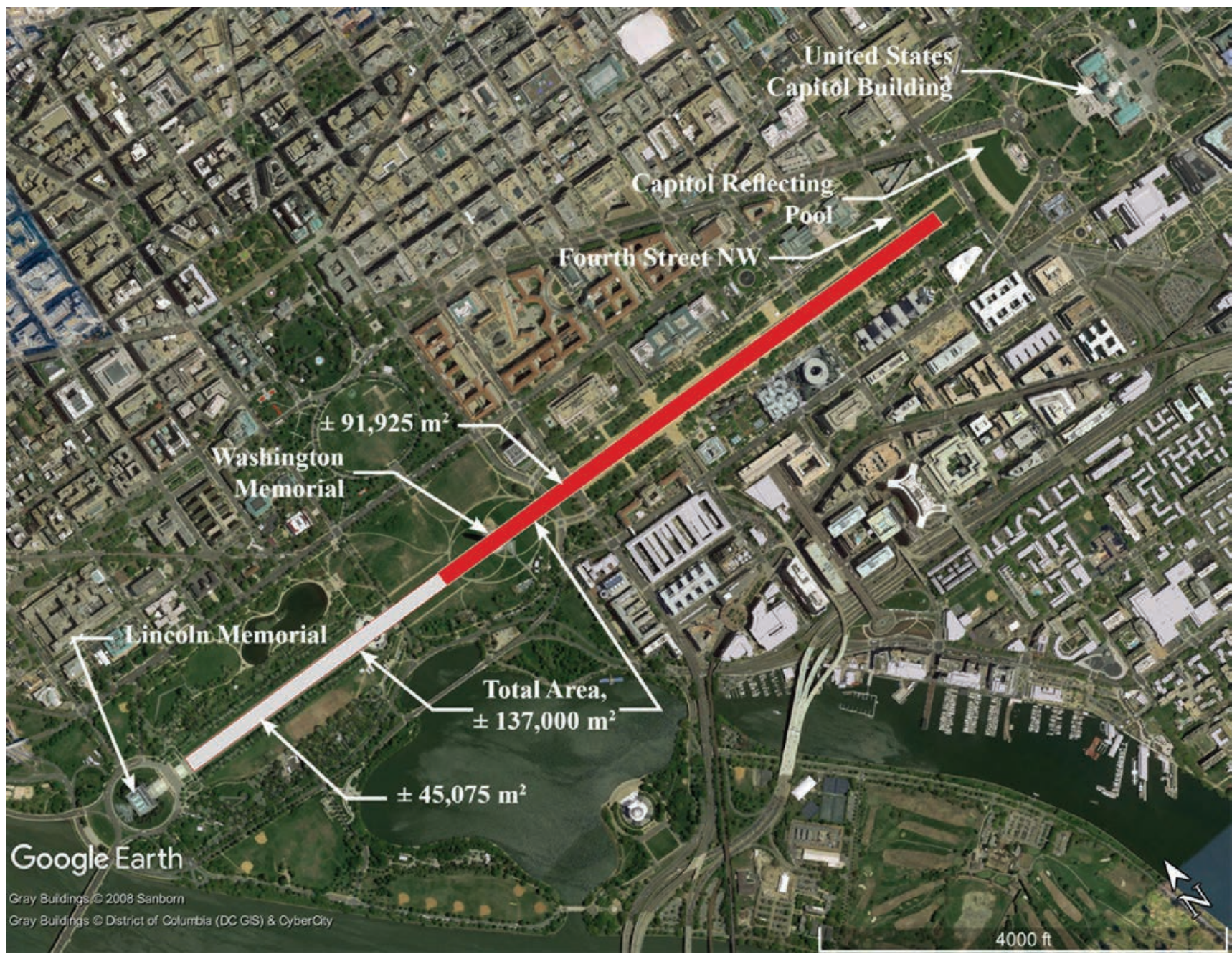

Figure 4

Aerial view of the National Mall, Washington, DC, illustrating the area of September Arctic sea ice loss associated with carbon dioxide emissions equal to that associated with air travel to ASLA annual meetings between 1960 and 2010, in solid gray; and between 2011 and 2019, in white.

front of the Lincoln Memorial in Washington, DC, if extended to 4th Street NW, a block west of the National Reflecting Pool (Figure 4). Overall, travelrelated emissions from ASLA meetings between 1960 and 2019 may contribute to a greenhouse warming effect equal to 72,670 to $141,871 \mathrm{tCO}_{2}$.

Using mean emission weights per meeting, and without accounting for radiative forcing, more than 1.91 million three-inch caliper sugar maples or their equivalent might remove the travel-related emissions from ASLA meetings between 1960 and 2019 over the course of one year. Alternatively, about 42,925 sugar maples could remove the travel-related emissions over 100 years. Thus, the elimination or drastic reduction of travel-related emissions associated with future annual meetings could result in the elimination or reduction of resources (i.e., trees, water, land, money, labor) that would be allocated to removing meeting-related emissions from the atmosphere to limit global warming to $1.5^{\circ} \mathrm{C}$.

Carbon dioxide emissions attributable to education session featured speakers' travel to ASLA annual meetings in 2011 and 2013-2019 appear to rise or fall due only to meeting locations. Emission estimations associated with each annual meeting gradually rose between 1960 and 2019. Perhaps annual meeting attendees perceive the practice of landscape architecture as a pro-environmental behavior, self-identify as environmentalists, and are genuinely concerned about and support policies 
related to climate change, yet feel little to no guilt when engaging in the carbon-intensive behavior of air travel, in comparison with other people (Lacasse, 2016). The absence of guilt may be due to the absence or possession of incorrect knowledge. In the United States, government documents do not suggest avoiding air travel as a means of reducing one's carbon footprint, despite the high impact of this action, relative to actions like recycling (Wynes \& Nicholas, 2017). Alternatively, attendees and ASLA may be willing to pay whatever taxes (e.g., carbon offsets for individuals and the society as a whole) are necessary to continue current meeting practices, expect that technological advancements in aircraft and carbon offsetting will allow for business as usual, redirect responsibility to others (i.e., the airline industry or government), or contest climate change and its relationship with air travel (Barr et al., 2010). Regardless, traveling by air to annual meetings to present or promote personal work, establish or maintain existing collaborations, and update or renew relationships with colleagues without presenting work may each be poorly justified actions in the current context of climate change (Le Quéré et al., 2015).

\section{CONCLUSIONS}

\section{Reimagining ASLA Annual Conferences}

Estimations of travel-related carbon dioxide emissions associated with ASLA annual meetings between 1960 and 2019 suggest that these meetingrelated activities may be inconsistent with the first standard of the society's own Code of Environmental Ethics (ASLA, 2017b), particularly regarding greenhouse gas emissions. Planned ASLA Conferences on Landscape Architecture in 2020 (Miami Beach), 2021 (Nashville), and 2022 (Seattle) suggest that the dissonance between the society's values and actions will continue, as will the associated climatic, social, and moral consequences of these actions. To achieve the goal of becoming a resource and organizational role model on environmental stewardship and contribute to international emission reduction targets, ASLA must immediately and dramatically reduce and ultimately eliminate future conferencerelated emissions. To that end, efforts should focus primarily on substantially reducing or eliminating attendees' air travel to and from conferences without the use of carbon offsets, which may erode support for more effective emission reduction strategies like carbon taxes (Hagmann, Ho, \& Loewenstein, 2019; Werfel, 2017). Carbon offsets may also contribute to overall emission growth and investment in projects that likely will not reduce targeted emission reductions (Anderson, 2012). Such efforts, if implemented successfully, may ensure that ASLA members and the general public view the society with the highest degree of credibility related to the climate crisis and support policies and strategies to address climatic change (Attari, Krantz, \& Weber, 2019).

Education session featured speakers. Introducing anonymity to education session submissions, evaluations, and selections for future ASLA conferences will not reduce travel-related conference emissions. However, it may decrease the concentration of presentations by a few individuals that is evident in the 2011 and 2013-2019 ASLA meetings. Until now, the ASLA requires each ASLA meeting education session proposal to include a biography of each speaker, which inherently introduces biases toward or away from the selection of session proposals that include certain people, titles, and institutions. Consequently, the implementation of an anonymous, double-blind peer review process should result in the selection of session proposals based on content alone (i.e., session title, marketing statement, learning objectives, outline, and references) and equitably distribute participatory opportunities to younger, entry- and mid-level landscape architects or allied professionals. Despite the use of an anonymous, peer-review process, some individuals and some institutions may still present more frequently than others due to differences in the numbers of employees, offices, and projects that exist across institutions.

My findings indicate that 4 to 10 meeting speakers $(M=7)$ have originated from locations outside North America each year (Table 4). Increasing ASLA membership is important, as is inclusivity and an awareness of international advancements in practice and knowledge. However, international speakers may be responsible for the highest emission values associated with travel to present for typically less than an hour at these meetings. Participation of international speakers in future 
conferences should occur only via telecommunications software.

By discussing the difficulties of changing carbonintensive behaviors, rather than continuing to fly and hiding it, landscape architects may increase their credibility and convince sceptics to act justly (Nordhagen et al., 2014). Speakers who present less, choose to participate remotely, or publicly reject an invitation to participate to avoid carbon emissions may be perceived as increasingly more credible and more likely to influence others to adopt low-energy behavioral changes.

Conference sites. Besides reducing travel-related carbon emissions, telecommunications software to convene future ASLA annual conferences may increase conference participation and attendance and decrease attendees' time and costs while retaining opportunities to interact and collaborate with others. At least three precedents exist. First, Arslan et al. (2011) described two "Workshops Without Walls" that organizers presented to more than 560 people in 31 states and 30 countries over three days. By using telecommunications software, organizers may have prevented the emission of 26 $\mathrm{tCO}_{2}$ into the atmosphere and saved 26 attendees a total of $\$ 20,000$ on airfare and $\$ 24,000$ on food and lodging. Seventy-six percent of workshop participants who completed a follow-up questionnaire reported they would not have traveled to attend the workshop. Fifty-five percent stated that they found or might find opportunities to collaborate. Second, the Nearly Carbon-Neutral Conference model developed by Ken Hiltner (2018) includes participant viewing of online prerecorded multimedia presentations. Attendees may choose to participate in an online question-and-answer forum over the course of two or three weeks. The benefits of this model include participation by presenters and attendees from almost anywhere; increased accessibility across financial, physical, visual, audio, language, and time zone differences; increased discussion among attendees; and increased efficiency of attendees' time. Similarly, the third precedent is the 2018 biennial Society of Cultural Anthropology (SCA) meeting. Planned over the course of one and a half years, the meeting used an online platform as the conference location and a commercially available website to store and stream over 100 prerecorded multimedia presentations (Pandian, 2018). Typically, past SCA biennial meetings attracted 200 attendees, most of whom originated from the United States. More than half of the 1,300 participants in the 2018 meeting represented more than 40 countries. Google Analytics indicated that 3,600 users accessed the website from 93 countries, including ten European, ten Asian, four African, and four Latin American conference hubs. Ninety-one percent of 155 presenters, organizers, and attendees expressed interest in participating in a similar conference. Three days of streaming videos and 2,389 hours of panel video presentations may have resulted in the emission of $1 \mathrm{tCO}_{2}$ and avoidance of an estimated $420 \mathrm{tCO}_{2}$ of emissions from air travel and $7 \mathrm{tCO}_{2}$ from hotel lodging and meeting spaces.

ASLA has its own precedents from which to draw and expand. Currently, ASLA administers online education sessions through Digitell (learn. asla.org/asla/pages/privacy_center). The ASLA website (learn.asla.org) contains recordings of ASLA meeting education sessions between 2016 and 2019. Following payment of an access fee, ASLA members can view recordings of more than 450 online learning presentations among twenty-two topic areas to gain professional development hours for retaining landscape architectural licensure or registration.

My results identify cities that may serve as regional hub locations for future annual conferences. At present, high concentrations of featured speakers from past conferences practice in each hub city (Table 3), which implies that the travel of landscape architects and other allied professionals to present and attend education sessions would be less likely to include air travel. For example, a conference hub location in the northeastern corridor of the United States could rotate among Boston, New York City, Philadelphia, Washington, DC, or Baltimore, which are connected by rail service. Alternatively, any of these cities could serve as a hub each year. Minneapolis and Chicago may serve as hubs in the Midwest, as could Kansas City, St. Louis, Cincinnati, and Cleveland; Atlanta may act as the Southern hub, along with New Orleans, Nashville, Orlando, and Miami; Houston and San Antonio may join Dallas and Austin as Texan hubs. Mountain West hubs 
include Denver, Albuquerque, and perhaps Phoenix. California hubs include San Francisco, Los Angeles, and Sacramento. Finally, Seattle and Portland could serve as hubs for the Pacific Northwest. Minimizing the number of hubs each year may encourage more physical interaction among attendees that practice in or near each hub city but increase travel-related carbon emissions. Although use of hub locations may minimize physical interaction between attendees from other cities in each region, they will minimize travel-related emissions, which is necessary for limiting global warming and the severity of the climate crisis.

Future research. Implications for future research follow from this study. Future work should estimate carbon emissions related to annual EXPOs that have coincided with annual meetings, particularly regarding exhibitors' travel and the transport of products to each meeting location. Accordingly, such estimations, along with cities of origin for products and product representatives, would inform the conduct of future EXPOs. Estimations of travel-related emissions associated with ASLA staff, general sessions, field sessions, and workshops at each annual meeting would contribute to a fuller understanding of carbon footprints generated by these meetings. Estimations of travel-related carbon dioxide emissions should be computed for all future ASLA conferences. Such action will enable a more complete accounting of conference-related carbon emissions. It will facilitate planning for future conference activities in a manner that explicitly considers carbon emissions.

Finally, estimations of travel-related emissions associated with other aspects of landscape architecture and allied professions should be conducted. For example, the methods used here might be applied to evaluate conduct of other meetings of landscape architects, including the annual conference of the Council of Educators in Landscape Architecture. The study's methods could be used to estimate carbon emission generated by activities associated with the Landscape Architectural Accreditation Board, Landscape Architecture Foundation, Cultural Landscape Foundation, and American Academy in Rome; university lectures, symposia, award juries, and travel for research and other purposes; and all aspects of project acquisition, design, and construction administration.

\section{REFERENCES}

Anderson, K. (2012). The inconvenient truth of carbon offsets. Nature, 484 (7392): 7.

Arslan, B. K., Boyd, E. S., Dolci, W. W., Dodson, K. E., Boldt, M. S. \& Pilcher, C. B. (2011). Workshops without walls: Broadening access to science around the world. PLoS Biology, 9(8), 1-5. https://doi.org/10.1371/journal.pbio.1001118

ASLA. (2011). ASLA Meeting and Expo, education sessions. ASLA. https://www.asla.org/2011meeting/EdSessions Sun1.html

ASLA. (2015). ASLA Meeting and Expo, full schedule: education sessions. ASLA. https://www.eventscribe.com/2015/ ASLA/aaSearchByDay.asp?h=Full\%20Schedule\&BCFO= P|FS|W

ASLA. (2016). ASLA Meeting and Expo, full schedule: education sessions. ASLA. https://www.eventscribe.com/2016/ ASLA/aaSearchByDay.asp?h=Full\%20Schedule\&BCFO= $P \mid G$

ASLA. (2017a). ASLA Meeting and Expo, education. ASLA. https://www.eventscribe.com//2017/ASLA/index.asp?

ASLA. (2017b). Code of environmental ethics. ASLA. https:// www.asla.org/ContentDetail.aspx?id $=4308$

ASLA. (2018). PHL2018 Annual Meeting and EXPO program. ASLA. https://www.eventscribe.com/2018/ASLA/

ASLA. (2019a). SAN2019 Conference on Landscape Architecture program. ASLA. https://www.eventscribe.com/2019/ ASLA/

ASLA. (2019b). For ASLA, addressing climate change is a stewardship obligation. ASLA. https://www.asla.org/land/ LandArticle.aspx?id=55255

ASLA. (2019c). Annual operating plan. ASLA. https://www. asla.org/uploadedFiles/CMS/AboutJoin/Leadership/ Leadership_Handbook/FY\%202019\%20Annual\%20 Operating\%20Plan.pdf

Attari, S. Z., Krantz, D. H., \& Weber, E. U. (2016). Statements about climate researchers' carbon footprints affect their credibility and the impact of their advice. Climatic Change, 138, 325-338. https://doi.org/10.1007/s10584-016-1713-2

Attari, S. Z., Krantz, D. H., \& Weber, E. U. (2019). Climate change communicators' carbon footprints affect their audience's policy support. Climatic Change, 154, 529-545. https://doi. org/10.1007/s10584-019-02463-0

Barr, S., Shaw, G., Coles, T., \& Prillwitz, J. (2010). "A holiday is a holiday": Practicing sustainability, home and away. Journal of Transport Geography, 18, 474-481. https://doi. org/10.1016/j.trangeo.2009.08.007

Bastin, J.-F., Finegold, Y., Garcia, C., Mollicone, D., Rezende, M., Routh, D., Zohner, C. M., \& Crowther, T. W. (2019) The global tree restoration potential. Science, 365, 76-79. https://doi.org/10.1126/science.aax0848 
Becken, S. (2002). Research note: The energy costs of the Ecotourism Summit in Quebec. Journal of Sustainable Tourism, 10(5), 454-456. https://doi.org/10.1080/096695802086 67180

Carbon Footprint. N.d. Carbon calculator. Retrieved from https:// www.carbonfootprint.com/calculator.aspx

Carbonfund.org. N.d. Individual calculator. Retrieved from https://carbonfund.org/individuals/

Chavaillaz, Y., Roy, P., Partanen, A.-I., Da Silva, L., Bresson, É., Mengis, N., Chaumont, D., \& Matthews, H. D. (2019). Exposure to excessive heat and impacts on labour productivity linked to cumulative $\mathrm{CO}_{2}$ emissions. Scientific Reports, 9, 13711. https://doi.org/10.1038/s41598-019-50047-w

Desiere, S. (2016). The carbon footprint of academic conferences: Evidence from the 14th EAAE Congress in Slovenia. EuroChoices, 15(2), 56-61. https://doi.org/10.1111/1746$692 \times .12106$

Fox, H. E., Kareiva, P., Silliman, B., Hitt, J., Lytle, D. A., Halpern, B. S., Hawkes, C. V., Lawler, J., Neel, M., Olden, J. D., Schlaepfer, M. A., Smith, K., \& Tallis, H. (2009). Why do we fly? Ecologists' sins of emission. Frontiers in Ecology and the Environment, 7(6), 294-296. https://doi.org/10.1890/09. WB.019

Fuss, S., Canadell, J. G., Peters, G. P., Tavoni, M., Andrew, R. M., Ciais, P., Jackson, R. B., Jones, C. D., Kraxner, F., Nakicenovic, N., Le Quéré, C., Raupach, M. R., Sharifi, A., Smith, P., \& Yamagata, Y. (2014). Betting on negative emissions. Nature Climate Change, 4, 850-853. https://doi. org/10.1038/nclimate2392

Grote, M., Williams, I., \& Preston, J. (2014). Direct carbon dioxide emissions from civil aircraft. Atmospheric Environment, 95, 214-224. https://doi.org/10.1016/j.atmosenv.2014.06.042

Guterman, L. (2009). Seeing green in conference season. Cell, 137, 1169-1171. https://doi.org/10.1016/j.cell.2009.06.003

Hagmann, D., Ho, E. H., \& Loewenstein, G. (2019). Nudging out support for a carbon tax. Nature Climate Change, 9, 484-489. https://doi.org/10.1038/s41558-019-0474-0

Hall. E. (2007). Alternative futures for academic conferences: A response to Bonnett. Area, 39(1), 125-129. https://doi. org/10.1111/j.1475-4762.2007.00732.x

Hiltner, K. (2018). A nearly carbon-neutral conference model: White paper/practical guide. https://hiltner.english.ucsb. edu/index.php/ncnc-guide/\#streaming

Hischier, R., \& Hilty, L. (2002). Environmental impacts of an international conference. Environmental Impact Assessment Review, 22, 543-557. https://doi.org/10.1016/S01959255(02)00027-6

Høyer, K. G. (2009). A conference tourist and his confessions: An essay on a life with conference tourism, aeromobility, and ecological crisis. Tourism and Hospitality Planning \& Development, 6, 53-68. https://doi. org/10.1080/14790530902847061

IPCC. (1999). Summary for policymakers. In Penner, J. E., Lister, D. H., Griggs, D. J., Dokken, D. J., \& McFarland, M. (Eds.),
Aviation and the global atmosphere. pp. v-13. Cambridge: Cambridge University Press. https://www.ipcc.ch/report/ aviation-and-the-global-atmosphere-2/

IPCC. (2014). Climate change 2014: Synthesis report. Contribution of Working Groups I, II and III to the fifth assessment report of the Intergovernmental Panel on Climate Change. Geneva: IPCC.

IPCC. (2018). Summary for policymakers. In Masson-Delmotte, V., Zhai, P., Pörtner, H.-O., Roberts, D., Skea, J., Shukla, P. R., $\ldots, \&$ Waterfield,T. (Eds.), Global warming of $1.5^{\circ} \mathrm{C}$. An IPCC special report on the impacts of global warming of $1.5^{\circ} \mathrm{C}$ above pre-industrial levels and related global greenhouse gas emission pathways, in the context of strengthening the global response to the threat of climate change, sustainable development, and efforts to eradicate poverty. pp. 3-24. Geneva: World Meteorological Organization. https://www.ipcc.ch/sr15/chapter/ spm/

Jungbluth, N., \& Meili, C. (2019). Recommendation for calculation of the global warming potential of aviation including the radiative forcing index. International Journal of Life Cycle Assessment, 24, 404-411. https://doi.org/10.1007/211367018-1556-3

Kavehei, E., Jenkins, G. A., Adame, M. F., \& Lemckert, C. (2018). Carbon sequestration potential for mitigating the carbon footprint of green stormwater infrastructure. Renewable and Sustainable Energy Reviews, 94, 1179-1191. https://doi. org/10.1016/j.rser.2018.07.002

Klöwer, M. (2019). The travel carbon footprint of the AGU fall meeting 2019. https://github.com/milankl/Carbon FootprintAGU.

Kroesen, M. (2013). Exploring people's viewpoints on air travel and climate change: Understanding inconsistencies. Journal of Sustainable Tourism, 21(2), 271-290. https://doi.org/10.1 080/09669582.2012.692686

Lacasse, K. (2016). Don't be satisfied, identify! Strengthening positive spillover by connecting pro-environmental behaviors to an "environmentalist" label. Journal of Environmental Psychology, 48, 140-158. https://doi.org/10.1016/j. jenvp.2016.09.006

Liu, H., Xu, Y. A., Stockwell, N., Rodgers, M. O., \& Guensler, R. (2016). A comparative life-cycle energy and emissions analysis for intercity passenger transportation in the U.S. by aviation, intercity bus, and automobile. Transportation Research Part D, 48, 267-283. https://doi.org/10.1016/j. trd.2016.08.027

Le Quéré, C. Capstick, S., Corner, A., Cutting, D., Johnson, M., Minns, A., Schroeder, H., Walker-Springett, K., Whitmarsh, L., \& Wood, R. (2015). Towards a culture of low-carbon research for the 21st century. Tyndall Working Paper 161. https://www.wcrp-climate.org/images/documents/jsc/ JSC36/twp161.pdf

Matthews. H. D., \& Solomon, S. (2013). Irreversible does not mean unavoidable. Science, 340, 438-439. https://doi. org/10.1126/science.1236372

McPherson, E. G., \& Kendall, A. (2014). A life cycle carbon dioxide inventory of the Million Trees Los Angeles program. 
International Journal of Life Cycle Assessment, 19, 1653-1665. https://doi.org/10.1007/s11367-014-0772-8

Morten, A., Gatersleben, B., \& Jessop, D. C. (2018). Staying grounded? Applying the theory of planned behavior to explore motivations to reduce air travel. Transportation Research Part F, 55, 297-305. https://doi.org/10.1016/j. trf.2018.02.038

Nevins, J. (2014). Academic jet-setting in a time of climate destabilization: Ecological privilege and professional geographic travel. Professional Geographer, 66(2), 298-310. https://doi. org/10.1080/00330124.2013.784954

Nihlén Fahlquist, J. 2009. Moral responsibility for environmental problems-Individual or institutional? Journal of Agricultural \& Environmental Ethics, 22(2), 109-124. https://doi. org/10.1007/s10806-008-9134-5

Nolt, J. (2011). How harmful are the average American's greenhouse gas emissions? Ethics, Policy, and Environment, 14(1), 3-10. https://doi.org/10.1080/21550085.2011.5611584

Nolt, J. (2013). Replies to critics of "How harmful are the average American's greenhouse gas emissions?" Ethics, Policy, and Environment, 16(1), 111-119. https://doi.org/10.1080/21550 085.2013 .768399

Nolt, J. (2015). Casualties as a moral measure of climate change. Climatic Change, 130, 347-358. https://doi.org/10.1007/ s10584-014-1131-2

Nordhagen, S., Calverley, D., Foulds, C., O'Keefe, L., \& Wang, X. (2014). Climate change research and credibility: Balancing tensions across professional, personal, and public domains. Climatic Change, 125, 149-162. https://doi.org/10.1007/ s10584-014-1167-3

Notz, D., \& Stroeve, J. (2016). Observed Arctic sea-ice loss directly follows anthropogenic $\mathrm{CO}_{2}$ emission. Science, 354(6313), 747-750. https://doi.org/10.1126/science. aag2345

Nursey-Bray, M., Palmer, R., Meyer-Mclean, B., Wanner, T., \& Birzer, C. (2019). The fear of not flying: Achieving sustainable academic plane travel in higher education based on insights from South Australia. Sustainability, 11(9), 2694. https://doi.org/10.3390/su11092694

Owen, B., Lee, D. S., \& Lim, L. (2010). Flying into the future: Aviation emissions scenarios to 2050. Environmental Science \& Technology, 44(7), 2255-2260. https://doi.org/10.1021/ es $902530 z$

Pandian, A. (2018). Reflections on \#displace18. Society of Cultural Anthropology. https://culanth.org/about/ about-the-society/announcements/reflections-ondisplace18

Roberts, I., \& Godlee, F. (2007). Reducing the carbon footprint of medical conferences. British Medical Journal, 334, 324-325. https://doi.org/10.1136/bmj.39125.468171.80

Spinellis, D., \& Louridas, P. (2013). The carbon footprint of conference papers. PLoS One, 8(6), 1-8. https://doi. org/10.1371/journal.pone.0066508
Stocker, T. F. (2013). The closing door of climate targets. Science 339, 280-282. https://doi.org/10.1126/science.1232468

Stohl, A. (2008). The travel-related carbon dioxide emissions of atmospheric researchers. Atmospheric Chemistry and Physics, 8, 6499-6508. https://doi.org/10.5194/acp-8-64992008

Stroud, J. T., \& Feeley, K. J. (2015). Responsible academia: Optimizing conference locations to minimize greenhouse gas emissions. Ecography, 38, 402-404. https://doi.org/ 10.1111/ecog. 01366

Union of Concerned Scientists. (2019). Each country's share of $\mathrm{CO}_{2}$ emissions. https://www.ucsusa.org/resources/ each-countrys-share-co2-emissions

Werfel, S. H. (2017). Household behavior crowds out support for climate policy when sufficient progress is perceived. Nature Climate Change, 7, 512-516. https://doi.org/10.1038/ NCLIMATE3316

Wynes, S., Donner, S. D., Tannason, S., \& Nabors, N. (2019). Academic air travel has a limited influence on professional success. Journal of Cleaner Production, 226, 959-967. https://doi.org/10.1016/j.jclepro.2019.04.109

Wynes, S., \& Nicholas, K. A. (2017). The climate mitigation gap: Education and government recommendations miss the most effective individual actions. Environmental Research Letters, 12, 1-9. https://doi.org/10/1088/1748-9326/ aa7541

AUTHOR CONTRIBUTIONS Rob Kuper is solely responsible for conducting the literature review, devising the study design and methodology; collecting, graphically presenting, analyzing and interpreting data; and preparing, submitting, and revising the manuscript for publication.

ACKNOWLEDGMENTS I greatly appreciate the time, attention, and effort that lan Bucacink, Archivist and Technical Librarian at the ASLA's Professional Practice Library, devoted to collecting, compiling, and sharing past meeting attendance numbers on which some of this research is based. I thank Charlene LeBleu, Interim Editor, for conducting the anonymous peer review of this study and coordinating the preparation of the manuscript for publication. I am grateful as well for the critical review of the manuscript for clarity by David Pitt, PhD, Interim Assistant Editor. I also extend my thanks to three anonymous reviewers who offered numerous clear, constructive and objective suggestions that improved the presentation of my study, and better prepared me for the conduct of future investigations. 
AUTHOR Rob Kuper is a licensed landscape architect in the commonwealth of Pennsylvania and an associate professor of landscape architecture at Temple University. He earned a BS in environmental design and an MLA from Auburn University. Past research interests generally involved the perception of landscapes, specifically with regard to time. His current and future research focuses on carbon emissions in landscape architecture teaching and practice.
PEER REVIEW STATEMENT This article was reviewed by three peer reviewers and a co-editor. Their contributions are gratefully acknowledged and appreciated. 